\title{
プロテウス感染を伴つた胎便腹膜炎例
}

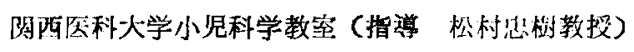

水野久子堀 あ き

\section{A case of meconium peritonitis with proteus infection}

\section{Hisako Mizuno and Asa Hori}

Department of Pediatrics, Kansai Medical School (Supervised by T. Matsumura)

プロテウス菌属は，現在のととろ古くから知ら れている P. vulgaris, P. morgani の他に P. mirabilis, P. rettgeri 及び Providencea に分けられ 広く土中, 水中或いは健康人糞便中或いは久滘 食品中にも見られ，病原性のないうのもあるが， 又下峲症の原因をなすのもある。

一方, 近時抗生物質使用のいちぢるしい発屡と 共に交代菌症の問題が大きくとりあげられ，プロ テウス菌もモニリア等と同様に交代の役割が演し られる事が知られている1。プロテウス菌の病原 性についての報告には, Cope and Kapser"), Wilson"),Cherry 等4)，Phillips") があるが，子供 に対するプロテウス症は少なく, Kollar ’ は 3\% と報告し，又 Graber $^{6)}$ は乳幼海下莉症341例 607 件中プロテゥス菌はわつが 20 例しか分離出来 ず，その陽性率は低いとのべている。

私は腹部膨満の主訴で生後 3 日目に入院し, 13 日目に開腹術をうけ, 穿孔性腹膜炎と診断され, 種々治療の甲斐なく死亡した新生児の生前並びに 剖検に際して各所よりプロテウス菌を検出した 1 症例を経験したので報告する。

症例生後 3 日目の男児, 満期安産, 生下時体 重は $3 \mathrm{~kg}$ である。

家族歴，母は出産 2 日前に夕食に市販のコロッ ケを食したとこ万, 夜半に腹痛を来たし, 暁方に 䓵吖，下峲 1 回ありて，1 日中悪心があつたとの 事である。他に特記すべき事はない。

\section{主訴, 腹部膨满}

現病歴，非下時よりやや腹部膨満があつたが， 次第にその程度を增し，更に1日2〜3回の嘔吐 （叶物は黄色，水様）を来たす様になり，呻吟，
苦閭状となつたので某医より腹腔穿刺をうけ先天 性気腹? といわれ $5 /$ III (生後 3 日目) に入院し た。便通は胎便が $3 \sim 4$ 问あり, 尚黄疸が昨日米 現われ始めた。

入院時所見, 体格小。栄養いちじるしく不良, 皮膚は黄色を帯び, 乾燥している。脈膊緊張良 好, 呼吸困難なし, 大泉門は $4 \times 4 \mathrm{~cm}$ 。前頭, 後 頭縫合は夫々重なつている。眼球結膜は黄色, 口腔粘膜は発赤, 乾燥し, 琶口癐はない。心, 肺 亿異常なし, 腹部は高度に膨隆し鼓腸及び静脈怒 張が著明である。尚下腹部には皮下気腫が見られ る。陰製も強度に腫脹。下肢は浮腫状で四肢硕冷 少ある。血液所見は赤血球数 505 万, 白血球数 4100 , 血色素量 $110 \%$ (ザーリ一氏法), 白血球分類は, 好中球 $68 \%$, 好酸球 $0 \%$, 単球 $1 \%$, 淋巴球 $30 \%$, Virocyte $1 \%$ で白血球数娍少にかかわらず白血球 の分類上からは軽度の炎症像を示している。胸腹 部のX線像は, 胸部には異常ないが, 横隔膜が強 度に挙上され，明らかに気腹を示していた。翌日 バリウム使用による腹部透視では, megacolonは 涊められなかつた。

入院後の経過並びに治療 高度の腹部膨満(余り にも強度のため皮庯が伸展され光沢をおびてい る）は 3 時開毎のガス抜き, 浣腸, 腹部温湿布等 によりやや軽減したかの如くに見えたが，8/III来 (入院 4 日月）再び高度となり, 湢吐頻々, しか も大量であり，旰吟あり，あたかも麻瘦性:イレウ スの状態を示した。葡萄煻,ビタミン郕, 抗菌䠼 (1日量としてストレプトマイシン $0.25 \mathrm{~g}$, ペニシ リン20万单位）に加えてワゴスチグミン $0.5 c C$ の 注射を行うと同時に，9/III腹腔穿刺を行い55cC排 


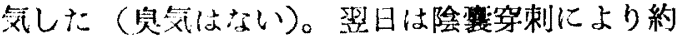
$7 \propto$ の排てを行つたが，排気当座の及腹部の膨隆

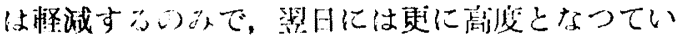

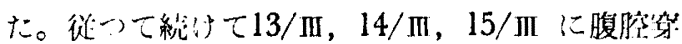

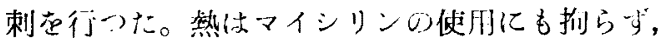

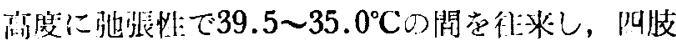
はつめたく，洁声微弱，蒱乳最も次籍に減少し

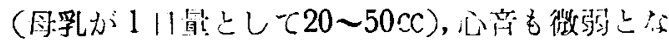
つて来たので，誌い切つて15/III（位後13|1「1） 外科にて阙腹術を能行した。剣状突起上り下約 7 cm の閒にメ又定人れ，開腹の結果 Plexus hepatics

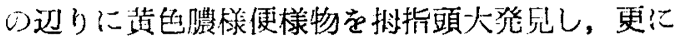
右側下腹部辺にも膿様物と思われる黄色索状物を

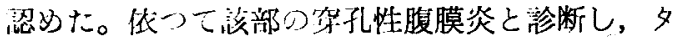
ンポンを㨉人し，手術は終つた。手術㭙の腹腔队 の膿様物より培養の結果 Proteus 菌を份離した。 手術後は铂日タンポンの交換, 藏萄糖, ビタミン 剂，ペニシリン，クロロマイセチンパルミテート 等の抗菌㑉をあたへ，栄養は母乳 1 日約 $20 〜 40 \mathrm{cc}$ の少量を飲み，全身衰弱次第に著明となりながら も生存していた。

然し時には专の乳房加ら直接に乳を吸う程の元 気のある時もあるし，注射により強く泣く時もあ つた。湢吐はあつたりなかつたりで，あれば非常 に大量で，色は緑色乃至黄色で粘液を混じ時々便 臭（?）が軽度にあつた。便は大抵浣腸により褐 色泥状便を排山したが，時には自然便を排出し た。20/孟 ガーゼに漿液性の液及び尚膿が附着し て来る事より，腹水もあるらしく，吻論まだ撚着 はない様である。23/III 頃は抱いて母親から 6 〜 7 回も乳が飲める程に元気が良かつたが，26/m 外科交換時に腹部の圧迫により黄色水様のものが 多量に排出される様になり（ウロビリノーゲン試 験 (一)), 其の頃から元気が更に㯖くなり, 哺乳 照す全くなく，口も開かず殆んど泣かず28/III（生 後26日目）汇死亡した。

\section{剖見時における主な所見}

1) 肉眼的所見：栄養著しく衰えた男児で皮下 脂肪織, 筋肉の発育甚だ不良, 黄瘟 (一), 出向斑 (一)。腹部は膨満しているか開腹による排気は悐 められない。諸腸（S字状結腸部を除く）は気を 容れる事大，殊に胃部のガス充満が目立つ。心蔵

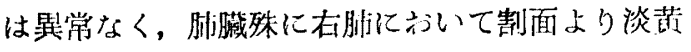

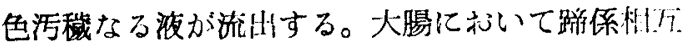

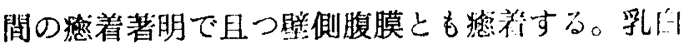

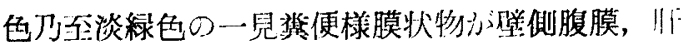

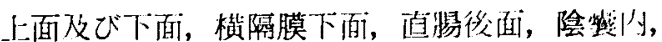

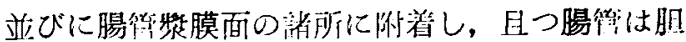
汁色に染志る。又䀴門より $43.2 \mathrm{~cm}$, 虫垂突起上

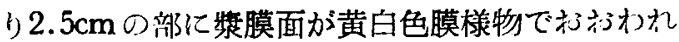
た直径 $2 \mathrm{~mm}$ の円形の穿孔がある。

2）鏡検的所見：心喊著変なし，肺藏，カタル 幽肺炎像あり，一般に Stase が著明。小腸，粘膜 面に壊死性膿様塊の認められる部位市り，粘膜下 組織，漿膜に浮腫㐫り，漿膜面には同在的な雨急 吽炎症柴あり，その部では多核白们球，淋巴球， 単球の混在する膿様塊が認められる。大腸，呀孔 部は他の腸管部の約1/3〜1/4の厚さにまで薄くなり 殊に筋屡に於いて著明であり，粘膜は粘膜固有板 より内面に扣いて㔀離され腸腺がー部楒められる のみである。孤在淋巴小結節は一般に站となり， 粘膜下組織に浮腯あり，細血管は充盈せず，との 部の墏膜面には異常を認めず，尚部分的に粘膜面 に出血巣や，壊死栄を認める。直腸，粘膜面に励 穢な Masse を附着する部位がある。环在淋巴小 結節はやや萎縮状。紐佔管は充盛し，漿膜面浮腪 状なり。肝蔵, Stase あり。俎栓, Kupffer's 星状 細胞の貪喰像, 汗紐胞内胆色素の存在が目立つ。 これは小葉中心部に多い。尚，中心静脈周辺部及 びグリソン氏鞘 の結合織が 部分的にやや增雃す る。腎臓，Stase が著明で殊に系䟵体に高度であ る。脾臓，へモジデロージス。白色骾は萎縮性。 その他内分泌諸臓器には異常を認好なかつた外， 副腎では皮質深層において充盈が顕著である。

\section{分離菌の生物学的, 血滦学的性状}

生前には手術時に施ける腹腔内の朖様物（15/ III), 黄色吐物 (19/III), タンポンガーゼ(22/III), 褐色泥状便 (24/而) 及び剖検時には，腸管附着 物 (緑色), 左右体壁腹膜に附着した乳白色の索状 物，直腸队便，陰铰队胀様物より表 Iに示す様な 生物学的﨡状を有する菌を分離した。それらの渚 性状の結果, Proteus mirobilis と同定した. Proteus hauseri O,HË血清による抗原構造は表 2 の 如くで，その結果より0〜10，H〜2 と決定した。 
第 1 表 分離菌の生物学的性状

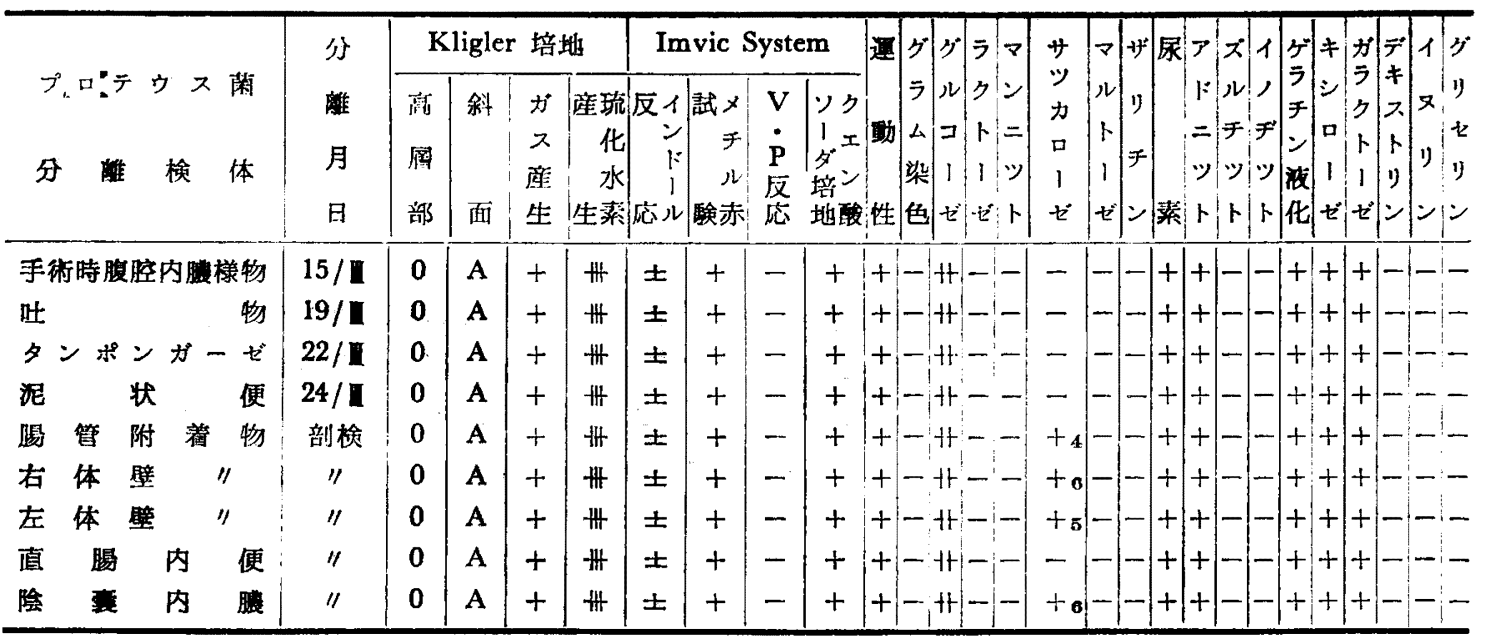

〔註〕判定は 1 週間判定とする。横の数字は陽珄になつた日を示す。

グルコーゼに扔ける+十は酸産生,ガス産生を示す。 A：酸産生。 O：不変

第 2 表 (a) 分離菌 Proteus hauseri O の血清に 対する凝集反応成績

\begin{tabular}{l|c|c}
\hline \multicolumn{1}{c|}{ 0-血清 } & 試験凝集反応 & 定量疑集反応 \\
\hline $0-1 \sim 9$ & - & - \\
$0-10$ (F73) & + & $1: 2560(+)$ \\
$0-11 \sim 49$ & - & \\
\hline
\end{tabular}

(b) 分觹菌の Proteus hauseri $\mathrm{H}$ 血清に 対する疑集反応成績

\begin{tabular}{l|c|c}
\hline $\mathrm{H}-$ 血 清 & 陚験疑集反応 & 定 量疑集反応 \\
\hline H-1 & - & ( \\
H-2 (F 403) & + & $1: 12800(+)$ \\
H-3 - 8 & - & $/$ \\
H-9 & - & \\
H-10 19 & - & \\
\hline
\end{tabular}

第 3 表 分離菌の各種抗生物質に対する感受性

\begin{tabular}{|c|c|c|c|}
\hline & 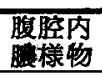 & 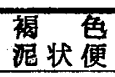 & 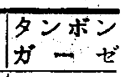 \\
\hline Sulfathiazol & 0 & $* 38 \times 38$ & $* 31 \times 31$ \\
\hline Penicillin & 0 & $\mathbf{0}$ & 0 \\
\hline Terramycin & $18 \times 18$ & $15 \times 15$ & $16 \times 15$ \\
\hline Aureomycin & $23 \times 23$ & $16 \times 16$ & $17 \times 17$ \\
\hline Chloramphenicol & $50 \times 45$ & $38 \times 38$ & $37 \times 38$ \\
\hline Streptomycin & $31 \times 31$ & 0 & $30 \times 30$ \\
\hline
\end{tabular}

〔辨〕数字は阻止带の大きさき示し，単位はnmであら はす。

*阻止带の不充分を示す。

尔離菌の抗生物筫並びにサルファ剂に対する感
受性。

実験は感応錠を用いて行つた (Denmark 製)。 その成績は表 3 亿示す如くで, Penicillin につよ い抵抗を示し，Chloramphenicol に対して最も良 く, 次が Streptomycin, Aureomycin, Terramycin の順となつている。 Sulfathiazol に対して は不完全な阻止带であつた。

\section{考按}

本例は，腸穿孔をともない穿孔性腹膜炎をおこ しだ新生児プロテウス疤:の 1 例である。穿孔性腹 膜炎は珍らしくないが，新生児に打ける報落は比 較的少ない。又手許にある外国交献によれば， Robert B. White (1956) は肛門閉寨の結果と しておこつた胎便腹膜炎を報告し，比較的稀なる のとしている。又 Bendel, Michel によつても10 万余人中に 3 例という頻度である。プロテウス菌 による中耳炎等の報告は度々あるが，プロテウス 菌による腹膜炎の報告はない。更に又穿孔性腹膜 炎の原因は大半が虫垂炎，蜔虫による腸穿孔等で あり，それらは新生児には先づ見られないもので あるから，生前に穿孔性腹膜炎の禞断をつける事 は非常にむつかしい，本例においても腹部膨满が 余りにも著明であり，渚種の治療によつても軽践 甘ず，依つて仕方なく手術を行い更に又剖検によ り亮度の腹膜炎の炎症と思われる澺着及び穿孔を 発見したものである。 


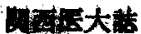

1949年に Low 達は 100 例以上ひ胎便腹膜炎を 報告しているが，この大半は検死に打いてたしか められている。新生児の腸管の呀孔の機㧫につい ては，植田氏7は新生児に打け\%直腸の Auer bach plexus の節細胞の消失に上りために機能的 に通過障碍が扔こり，これが鼓陽，便佖という㾦: 状を扣てし遂に穿孔が扣てるとの心゙ている。本例 においては，組織学的には節細胞の消失は兒られ ず证常の状態にむつた。又 I. Blanche Bourne ${ }^{8)}$ は生後 3 日目の新生児にれいて先天性に下部回腸 の閉塞があり，ために腹腔内圧がれか竞り，穿孔 『扎しし，胎便によつて扔てつた腹膜炎の剖検例 蛋趼告して扔り（原因菌は記載されていない）, 更 亿又 Robert B. White' をその原因を先天性, 後 天性の閉塞のため, 閉塞なしの外傷性のもの, 腸 篦に衿ける限局性の久損のための自発性の穿孔と のべており，1例の畂閏閉塞によつて48時間後に 腹部膨隆つ形で示されて来た胎便腹膜炎を併つた 第孔腸つ 1 例を報告している。本例に於ては, 腸 管，及び肛門開塞などは見られなかつた。彷つて 本例に打ける穿孔は何によつて扢てつたがの成 因は明らかでない。腸穿孔は本例に扔いては上行 結腸に相当する部分即ち肛門より $43.2 \mathrm{~cm}$ のとと 万にあつた。Robert は Sigmoid の前方に, Blanche Bourne は最も㞗々回腸下部にあり，十二 指腸, 空腸, そして大腸の閉塞が之につぐとのべ ている。

次に検出したプロテウス菌について考えて見る と, 生後間もなくの検便が出来ていないので何と むいえぬがその後に扔いて本例は検便毎に全然大 腸菌を証明し得ず，プロテウス菌を平板上に純培 養に分離した事, 尚手術侍, 剖検特にる同様な菌の みを得ている事等より考えて，本例をブロテウン 症と考元てよいと思う。プロテウス菌は，小笠原 氏等 ${ }^{10}$ は日常食品中に $18 \%$ 亿見出され，魚介類の みでは $25.8 \%$ とのへている。又志賀氏 ${ }^{11)}$ 日常食 品中のプロテウス菌の出現頻度を調査し, 魚介類 25\%内外, 食肉, 野菜 4 8\%内外で， その型は P. vulgaris, P. mirabils であり, (P. morgani は ないとの心ててる。ての様にプロテウス菌は日常 食品中にも見られる程であり稆原性のないものも あるし，又下菽症の原因をなす場合もあるが，本

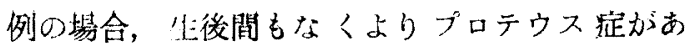
り，更に腹部膨湳，熱動動があり一進一退のため 遂に手術を䘕い第孔性腹膜炎との彰断をうけ，其 の後殆んど栄養らしいものもとれていないにも拘 らす27日開も生存していたという事は本プロテウ ス菌の病原性が強くなかつた牙を裏づけるもので ある。文、マウスに括ける毒性試験に扔いては0.3 mg でも全例死亡しなかつた。次にプロテウス菌 が何時体内に侵人し，どうして腸管全体に繁殖し てしまつたかについては，小張氏 ${ }^{19}$ に打ける大腸 菌は生後何時から腸管内にすむ様になるかの調べ では，早いものは出生当日，普通は $2 \sim 3$ 日，抒 そいものでも 7 日となつている。との数字は哭菌 的の環境にある新生児室に打けるものであり，一。 般では勿論如何に早くから大腸菌が新生巟の腸管 にすむ様になるかと思われる。本例は生後 1 週閒 以內には検便が出来なかつたが, 其の後の $2 \sim 3$ 回の検便においても培養成績からは全然大腸菌の 侵入は見られず，每回プロテウス菌のみ純培養に 分離した事等考えると本例の腸管内では大腸菌ぶ 侵入し，繁殖しない程プロテウス菌の: Hauchbildung の作用つよく,ために強度にプロテウス菌 が繁殖していき, 吐物中にる Streptococcus faecalis と共に本菌を証明した事より腸管のみなら ず更に㥜内にまで本プロテウス菌の侵襲があつた ものと考えられる。

食中毒の原因には色々あるが佐竹氏日報告に よれば，サルモネラが一番多く，次いでブドー球 菌, プロテウス菌となつて打り，プロテウス菌も かなり見られるものである。本例において母親の 䔬便中からプロテウス菌を分離し得なかつたけれ ど（気がついたのが後日のため，検便したが琎明 しなかつた）母親のコロツケによると思われる腹 痛, 下莉, 嘔吐がプロテウス菌による食中毒と見 なし, 出産時に尚産道附近が本菌により污染され ていたために，思児が出産時に経口的にプロテウ ス菌を母親からもらつたものと思われないだろう か。

以上述べだ様な事柄は比較的珍らしいものであ り，出産前の母親の衛生について注意すべき事項 の一つとして重要と思われる。 


\section{結語}

生後26日目の新生児の腸管穿孔を伴つたブロテ ウス症について述べた。

1）穿孔は畂門から $43.2 \mathrm{~cm}$ のところにあり， 直径 $2 \mathrm{~mm}$ の円形であつた。組織学的に局所は粘 膜下組織がうすくなり，浮腫があるが積極的な細 胞浸潤は見られない。

2）生前並びに剖検時に分離したブロテウス菌 のすバては諸程生物学的性状より Proteus mirabilis と固定した。その抗原構造は0〜10, $\mathrm{H} \sim 2$ である。

3）本症は出産時に母親から産道感染によつて プロテウス菌をもらつたものと推定する。

稿を終るにあだりまして, 分離菌の血清学的晾断に御 援助いたぐきました神戸市衛生研究所長堸氏並びに本学 微生物更に外科, 病理学教室に謝意を表すると共に, 御 校閲並びに御指導いだざきました松村教授に感謝し厚く 御礼申しあげます。
（本槁の要旨は昭和31年 6 月 30 日大阪地方会にて発表し た)

\section{女 献}

1) 奥山虎二：小児科款燎，19 (5) 65, 昭 31

2) Cope and Kapser: J. Bakt, 57, 259, 1949

3) Wilson: The Practitioner, 162, 445, 1949

4) Cherry : A.J.Pub. Hl, 36 (5) 484, 1946

5) Phillips: J. Hygiene, 53 (2) 212, 1955

6) Graber : Pediatrics, 16 (5) 585, 1955

7) 植田隆他：小児科臨床，9 (1) 95, 明31

8) 1. Blanche Bourne: J. Pediatrics, 48 (2) 2201956

9) Robert B. White : J. Pediatrics, 48 (6) 7931956

10）小笠原竜雄他：千葉大学窝敗研究所報告，16，52, 昭28

11) 志賀信雄他: 千莱医学会雑誌, 29 (3) 259 , 昭 28

12) 小張一峰：日本层染病学会雑誌，29(2) 昭30

13）佐竹男他：公臬衙生，16（3）1, 昭29 